\title{
Diversity and Distribution of Natural Populations of Eucheuma J. Agardh and Kappaphycus Doty In Nusa Tenggara Barat, Indonesia
}

\author{
Sunarpi ${ }^{1}$, Mursal Ghazali ${ }^{1}$, Aluh Nikmatullah²*, Phaik-Eem Lim ${ }^{3}$, Siew-Moi Phang ${ }^{3}$ \\ ${ }^{1}$ Faculty of Mathematics and Natural Sciences, University of Mataram, Jalan Majapahit 62 Mataram, 83217 Indonesia \\ ${ }^{2}$ Faculty of Agriculture, University of Mataram, Jalan Majapahit 62 Mataram, 83217 Indonesia. \\ ${ }^{3}$ Institute Ocean and Earth Sciences, University of Malaya, 50603 Kuala Lumpur, Malaysia. \\ *aluhnikma@hotmail.com (corresponding author)
}

\begin{abstract}
The genera Kappaphycus Doty and Eucheuma J. Agardh are amongst the most economicallyimportant seaweeds in Indonesia. Several species of Kappaphycus and Eucheuma are cultivated in many farms in Indonesia including Nusa Tenggara Barat (NTB). However the cultivated Kappaphycus is influenced by environmental changes. Variation in seaweed germplasm is necessary in order to produce elite lines with required quantity. More than 10 wild specimens of Eucheum/Kappaphycus species are obtained in the NTB marine waters, including E. spinosum (green and brown), E. striatum (green and brown), Eucheuma/Kappaphycus sp-1 and Eucheuma/Kappaphycus sp-2. Distribution of the species in NTB has been mapped, showing that Lombok Island has more diverse species of Eucheuma compared to Sumbawa Island. In addition, morphological and physiological characterisation of the species have been undertaken, and it is observed that there are morphological differences in the same species obtained from different coastal zones, and thus indicating morphological plasticity of the species to different environmental conditions.
\end{abstract}

(Keywords: West Nusa Tenggara, E. spinosum, E. striatum, E. edulis, E. serra, natural diversity, seaweeds)

\section{INTRODUCTION}

The genera Kappaphycus Doty and Eucheuma J. Agardh are currently considered as the most economically important seaweeds in the world. The two genera serve as raw materials for carrageenan, a major component of dietary fibre [1] which is used as stabilizer, gelling agent, thickener, binder and additive in various food and pharmaceutical industries [2]. Today Kappaphycus alvarezii is a major cultivated carrageenan-producing species in Indonesia followed by $K$. striatum and Eucheuma spinosum. In addition, the production and processing of these species have become a highly valuable and profitable livelihood activity in many marginal seafarming communities in Indonesia including West Nusa Tenggara.

It is suggested that the two most commercially cultivated species of $K$. alvarezii strain Tambalang and $K$. alvarezii strain Moumere are introduced species from the Philippines. The seedlings of Kappaphycus and Eucheuma are obtained only by vegetative propagation, and therefore the same strains dominate seafarming in Indonesia. K. alvarezi has been introduced to more than twenty countries with two reported cases where
Kappaphycus plants have spread from the introduction sites and adversely impacted the native habitats [3]. In addition, it is suggested that $K$. alvarezii is less adaptive to environmental changes and impacts of clmate change, as indicated by the occurrence of thallus bleaching and thus production reduction of $K$. alvarezii by more than $50 \%$ [4] when the seawater temperature increased by $2^{\circ} \mathrm{C}$ in Nusa Lembongan, Bali. Similarly, the National seaweed production in Indonesia also decresased in 2010. Therefore, the use of elite and more adaptive varieties developed from native species will be more favourable to environmental variation. Such strain is yet to be available.

This paper presents the diversity and distribution of Eucheuma and Kappaphycus collected from cultivation sites and from the wild populations of the NTB marine waters. Nusa Tenggara Barat is a province in central Indonesia with two main and many small islands, and located between the Wallace's and Weber's Lines. This information is important for both understanding the seaweed biodiversity in the NTB as well as contributing to the development of elite Kappaphycus and Eucheuma strains for cultivation. 


\section{MATERIALS AND METHODS}

Eucheuma and Kappaphycus samples were collected from various locations around Nusa Tenggara Barat. The cultivated samples were obtained from various seaweed farms in Lombok and Sumbawa islands (Pengantap, West Lombok,; Gerupuk, Central Lombok; Serewe, East Lombok; Teluk Ekas, East Lombok; Kertasari, West Sumbawa; Labuhan Mapin, Sumbawa; Terano, Sumbawa; Hu'u Dompu, and Teluk Waworanda, Bima). Wild samples were collected from locations away from seaweed farms and they were collected from Gili Indah (Gili Air, Gili Meno and Gili Trawangan - North Lombok), Gili Genting and Bangko-Bangko (West Lombok), Tanjung Ann and Kute (Central Lombok), Teluk Ekas, Labuan Haji, Pulur (East Lombok). Teluk Kaung (Sumbawa) and Jelenge (West Sumbawa). The samples were observed for general morphology, then preserved as herbaria and for carrageenan content determination. Carrageenan (semi-refined carrageenan) was extracted according to method described by Misha et al. (2006) with some modification. To extract the semirefined carrageenan, $3 \mathrm{~g}$. of dried-seaweed was placed in a jar containing $150 \mathrm{ml}$ of $\mathrm{KOH}$ solution ( $\mathrm{pH}$ 9.0) $(1: 50, w / v)$, and heated in a water bath at $c a .90^{\circ} \mathrm{C}$ for 3 hours with frequent stirring. The mixture was filtered, and the supernatant was placed again in a water bath for another 2 to 3 hours until the volume was reduced by half. The supernatant was cooled at room temperature for 1 hour, and the gel was precipitated with $225 \mathrm{ml}$ of ethanol (96\%) (1:3, v/v), and incubated overnight. Semi refined carrageenan was separated by filtration and dried at $60^{\circ} \mathrm{C}$ for 2 days.

All molecular work (DNA isolation, amplification cox 2-3 spacer, and sequencing) was undertaken at the Institute of Ocean and Earth Sciences (IOES, University of Malaya, Malaysia). Isolation of genomic DNA, amplification of mitochondrial cox2-3 spacer molecular marker and sequencing was undertaken as described by [5].

\section{RESULTS AND DISCUSSION}

\section{Kappaphycus and Eucheuma from cultivation areas in NTB .}

Survey of cultivated species in NTB resulted in 10 specimens which can be grouped into seven cultivated varieties, i.e six varieties of Kappaphycus and one variety of Eucheuma. They are K. alvarezii Tambalang brown, K. alvarezii Tambalang green, K. alvarezii Moumere brown, $K$. alvarezii Moumere green, $K$. striatum brown, $K$. striatum green, and E. spinosum (Table 1, Figure 1 to 5). Based on these collections, the distribution of cultivated and wild Kappaphycus and Eucheuma in Nusa Tenggara Barat are mapped for Lombok Island and is presented in Figure 8.

The morphology of cultivated $K$. alvarezii obtained from different locations is quite similar, with few morphological variations occurring in color and size depending on the location. For example, the thallus size and height of plants cultivated in Lombok Island were smaller than those in Sumbawa Island. In addition the variant obtained in Lombok Island has lighter color than the variant obtained from Sumbawa Island. Similarly, K. alvarezii strain Tambalang green obtained from Gerupuk (Central Lombok) has lighter color than that obtained from Pengantap (West Lombok) (Table 4, Appendix 1). More distinct morphological differences can be seen between K. alvarezii Tambalang and $K$. alvarezii Moumere. The Moumere has bigger, bluntended thallus with nodulation (tumor-like nodule) on the thallus surface while the Tambalang has smooth surface and thallus with pointed end.. It has also fewer branches than the K. alvarezii Tambalang. The K. striatum has also very similar characteristics but is different from the $K$. alvarezii Tambalang and Moumere. The $K$. striatum has lighter color, short thallus, more branches and dichotomus- or trichotomus-type of branches while $K$. alvarezii has verticullate-type of branches with long thallus. The green K. striatum was obtained in three cultivated areas, namely Pengantap (West Lombok), Serewe (East Lombok) and Kertasari (West Sumbawa) while the brown one was obtained only from Pengantap (West Lombok). With regards to E. spinosum, quite similar morphology was seen between the variant cultivated in Pengantap and Serewe, with both having spines and cartilaginous thallus.

\section{Ecotype of Kappaphycus and Eucheuma from NTB .}

Survey of wild species in NTB resulted in nine specimens which can be grouped into five ecotypes of E. spinosum and four uncharacterized Eucheuma/ Kappaphycus variants (Table 3, Figure 6 and 7). The $E$. spinosum can be recognized by spines observed in the branch, and they are quite similar in morphology with cultivated species with some variation in color, size and branch type. The other uncharacterized groups are similar to Eucheuma and Kappaphycus, and they are 
Table 1. Cultivated species of Kappaphycus and Eucheuma in Nusa Tenggara Barat

\begin{tabular}{|c|c|c|}
\hline No & Location & Species \\
\hline 1 & Pengantap, West Lombok & $\begin{array}{l}\text { 1. E. spinosum } \\
\text { 2. K. striatum (brown) } \\
\text { 3. K, striatum (green) } \\
\text { 4. K. alvarezzii Tambalang (green) }\end{array}$ \\
\hline 2. & Teluk Gerupuk, Central Lombok & $\begin{array}{l}\text { 1.K. alvarezii Moumere } \\
\text { 2. K. alvarezii Tambalang brown } \\
\text { 3. K. alvarezii Tambalang greem }\end{array}$ \\
\hline 3. & Serewe, East Lombok & $\begin{array}{l}\text { 1. K. alvarezii Tambalang brown } \\
\text { 2. E. spinosum } \\
\text { 3. K. striatum green }\end{array}$ \\
\hline 4. & Teluk Ekas, East Lombok & $\begin{array}{l}\text { 1. K. alvaresii Tambalang brown } \\
\text { 2. K. alvarezii Moumere }\end{array}$ \\
\hline 5. & Kertasari, West Sumbawa & 1. K. striatum green \\
\hline 6. & Labuan Mapin, Sumbawa & 1. K. alvarezii Tambalang brown \\
\hline 7. & Terano, Sumbawa & 1. K. alvarezii Tambalang brown \\
\hline 8. & Hu’u Lakey Dompu & 1. K. alvarezii Tambalang brown \\
\hline 9. & Teluk Waworoda, Bima & 1. K. alvarezii Tambalang brown \\
\hline
\end{tabular}
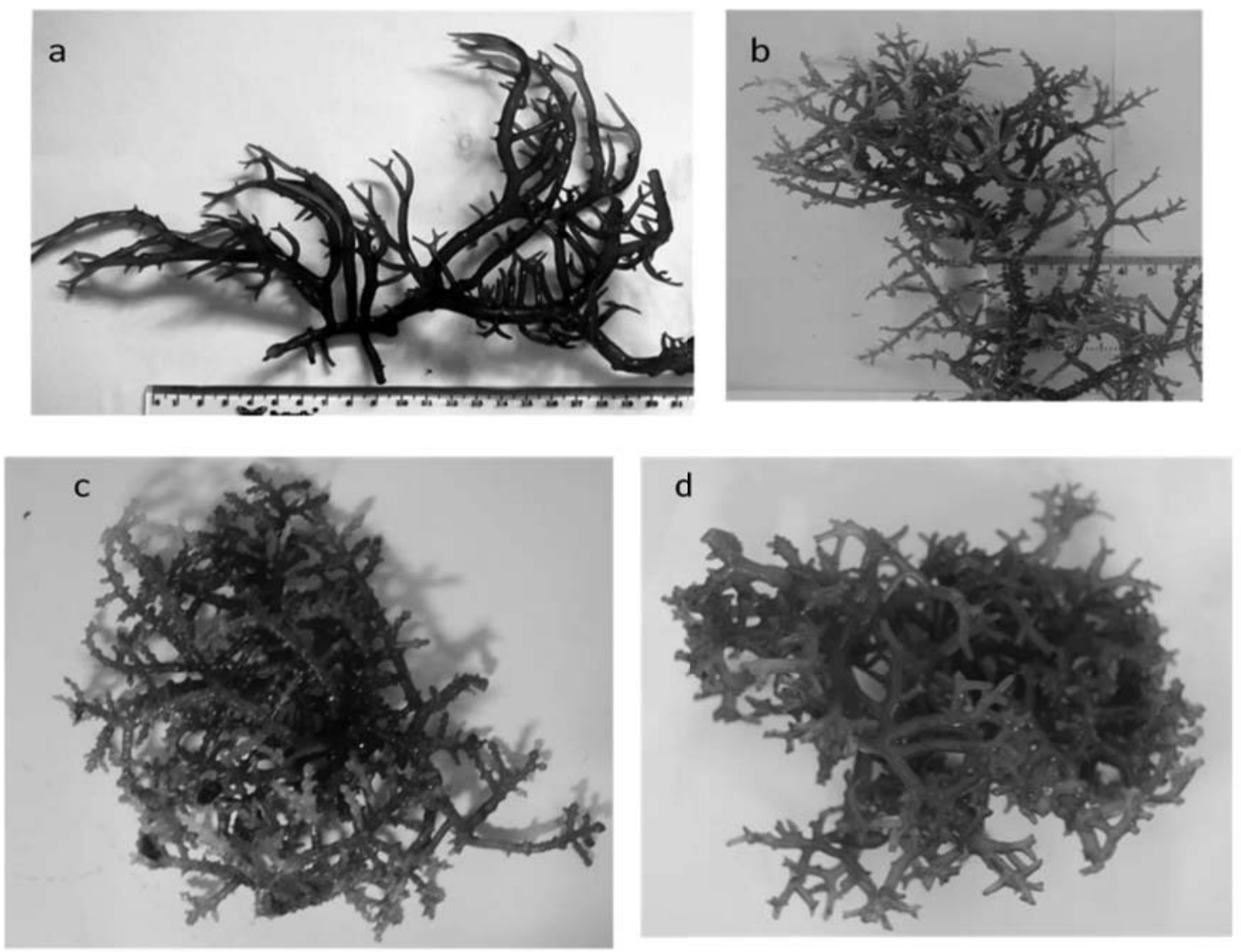

Figure 1. Four varieties of Eucheuma and Kappaphycus collected from cultivation areas in Pengantap, West Lombok are Kappaphycus alvarezii Tambalang green (a), Eucheuma spinosum (b), Kappaphycus striatum brown (c) and Kappaphycus striatum green (d). 

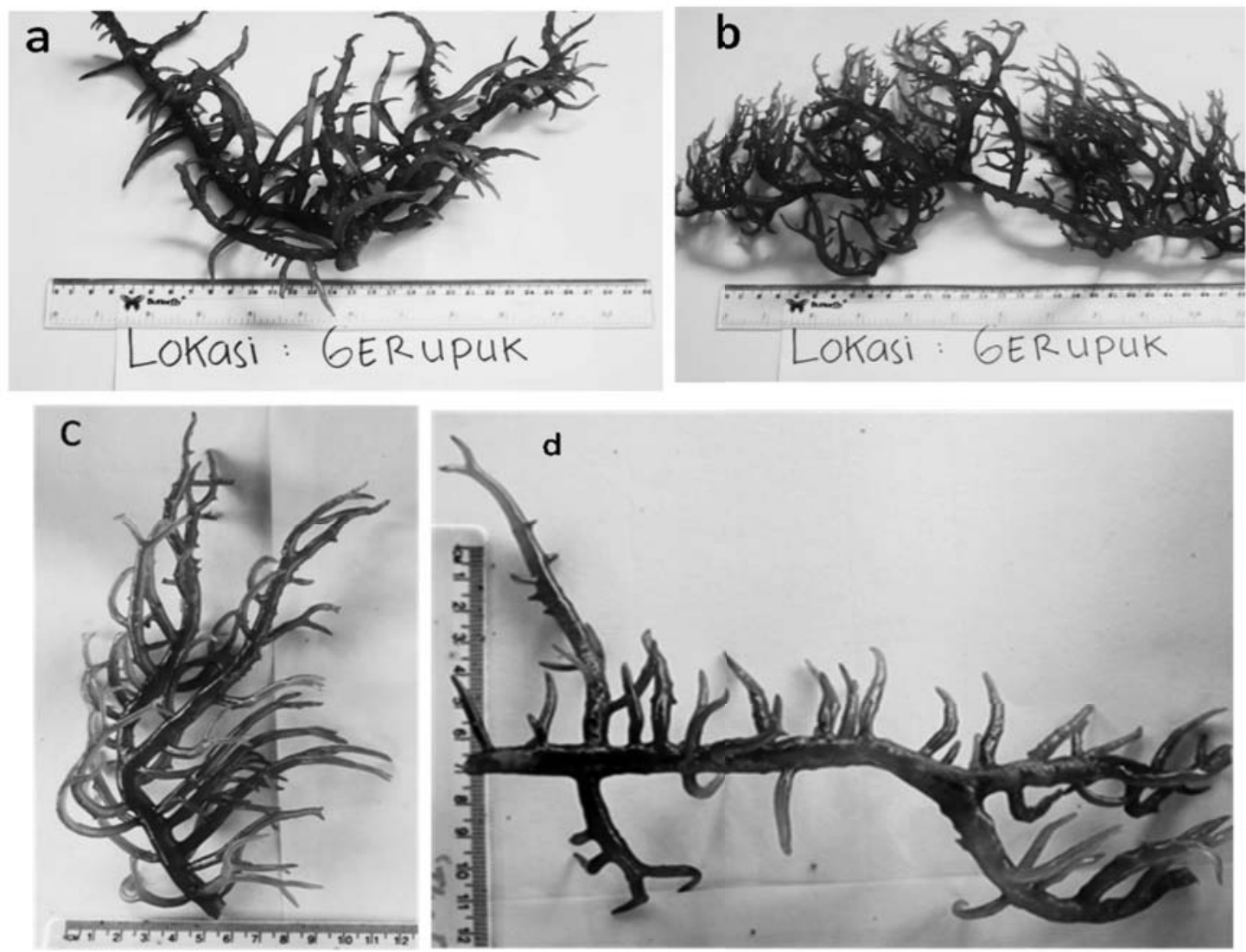

Figure 2. Three varieties of Kappaphycus collected from cultivation areas in Gerupuk, West Lombok are Kappaphycus alvarezii Moumere brown (a), Kappaphycus alvarezii Tambalang brown (b) and Kappaphycus alvarezii Tambalang green (c). Sometimes the Kappaphycus alvarezi Tambalang have a combined colour of brown and green (d).
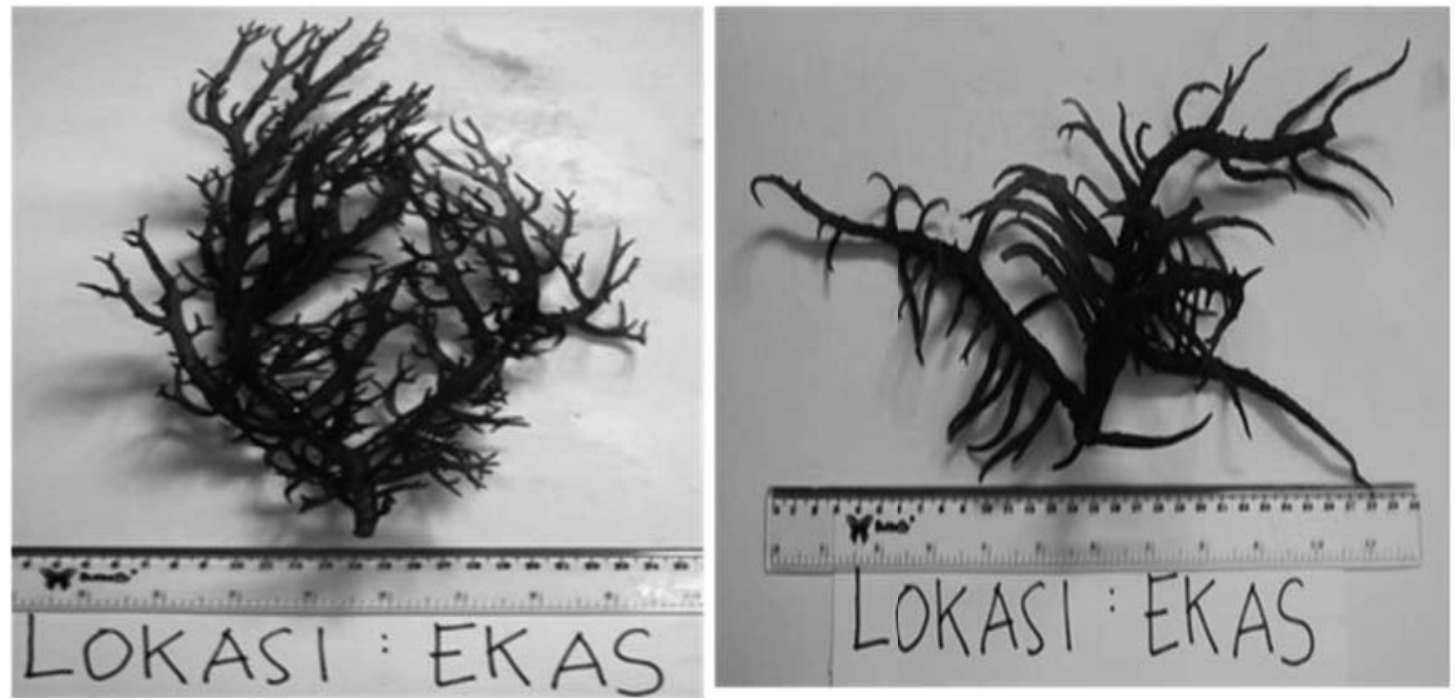

Figure 3. Two varieties of Kappaphycus collected from cultivation areas in Teluk Ekas, East Lombok are Kappaphycus alvarezii Tambalang brown (a) and Kappaphycus alvarezii Moumere brown (b). 

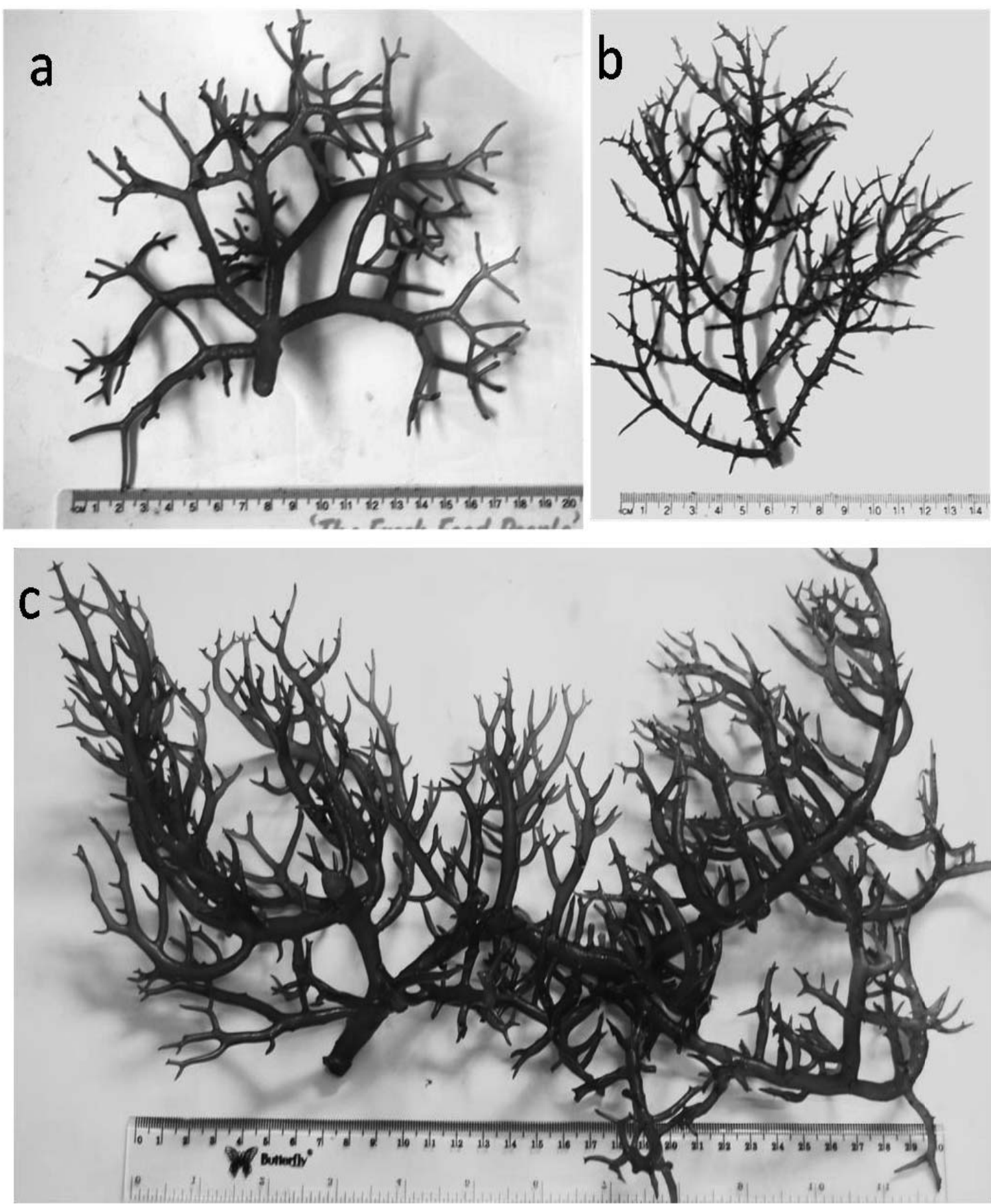

Figure 4. Three varieties of Eucheuma and Kappaphycus collected from cultivation areas in Serewe, East Lombok are Kalvarezii Tambalang brown (a), K. striatum green (b), and (c) and E. spinosum (c). 

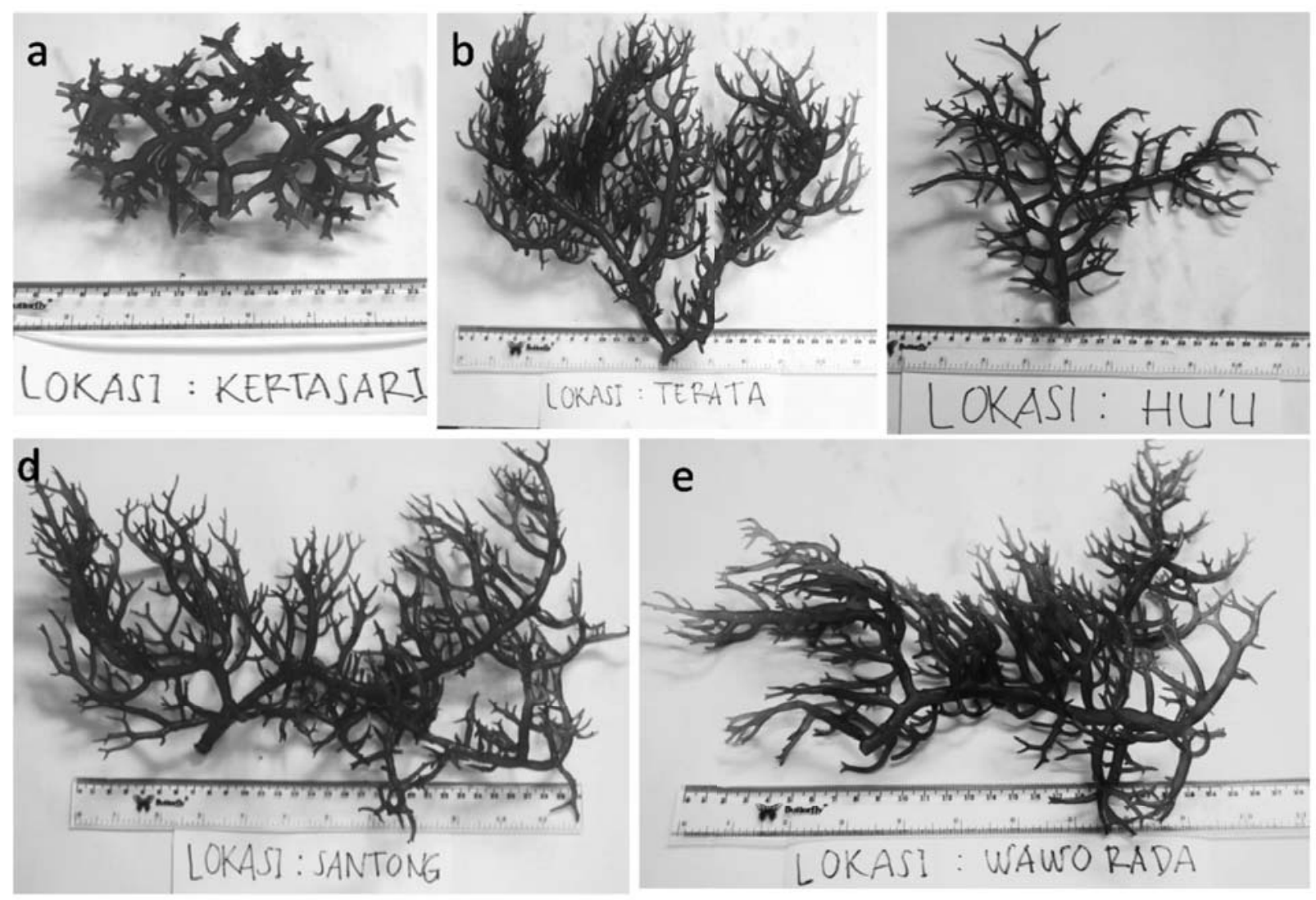

Figure 5. Three varieties of Kappaphycus collected from cultivation areas in Sumbawa Island are K striatum green (a; Kertasari, West Sumbawa), K. alvarezii Tambalang brown (b; Terata - Sumbawa), K. alvarezii Tambalang brown (c; Hu'u, Dompu), K. alvarezii Tambalang brown (d; Teluk Santong, Sumbawa), and K. alvarezii Tambalang brown (e; Teluk Waworada, Bima).

grouped with the ecotype obtained in Ekas Bay and subjected to molecular characterization.

Analysis of semi-refined carrageenan indicates that the carrageenan content of all samples are between 40 to $50 \%$ of dry-weight (Figure 9 ). Similar quantities of carrageenan was obtained from different variants of $K$. alvarezii Tambalang (brown and green), K. alvarezii Moumere, K. striatum (green and bown), E. spinosum (cultivated and wild). The carrageenan contents were not analyzed for Eucheuma/Kappaphycus sp. 1 and sp. 3 since there were inadequate samples available for the extraction at the time of this experiment.

\section{Molecular Characterization}

There is difficulty in characterization of the ecotypes based on morphological characters, therefore the use of mitochondrial cox2-3 spacer molecular marker for identification of wild Eucheuma/Kappaphycus in NTB was attempted. DNA was isolated from eight samples of cultivated and wild Eucheuma/Kappaphycus in NTB including E. spinosum (cultivated Serewe), E. spinosum (wild Ekas), K. striatum green (cultivated Pengantap), K. striatum brown (cultivated Pengantap), Eucheuma/Kappaphycus sp. 2 (Jelenge, Sumbawa), Eucheuma/Kappaphycus sp. 3 (Jelenge, Sumbawa) and Eucheuma/Kappaphycus sp. 4 (Kaung, Sumbawa). The DNA (6 bands of ca. 300 bp) obtained (Figure 10) were sent for gene sequencing. The contiqs generated from sequences (Table) were blasted against NCBI nucleotide $(\mathrm{nt} / \mathrm{nr})$ database. Blast analysis of the tree sequences reveled that they have very high similarities (97-100\%) with different isolates of $E$. denticulatum (ascension numbers JN980403.1; JX624081; JN234758; JN234756; JX624082; AY687429 and many more sequences of $E$. denticulatum in the GeneBank database).

The survey on Kappaphycus and Eucheuma in Nusa Tenggara Barat revealed that the cultivated variant in 

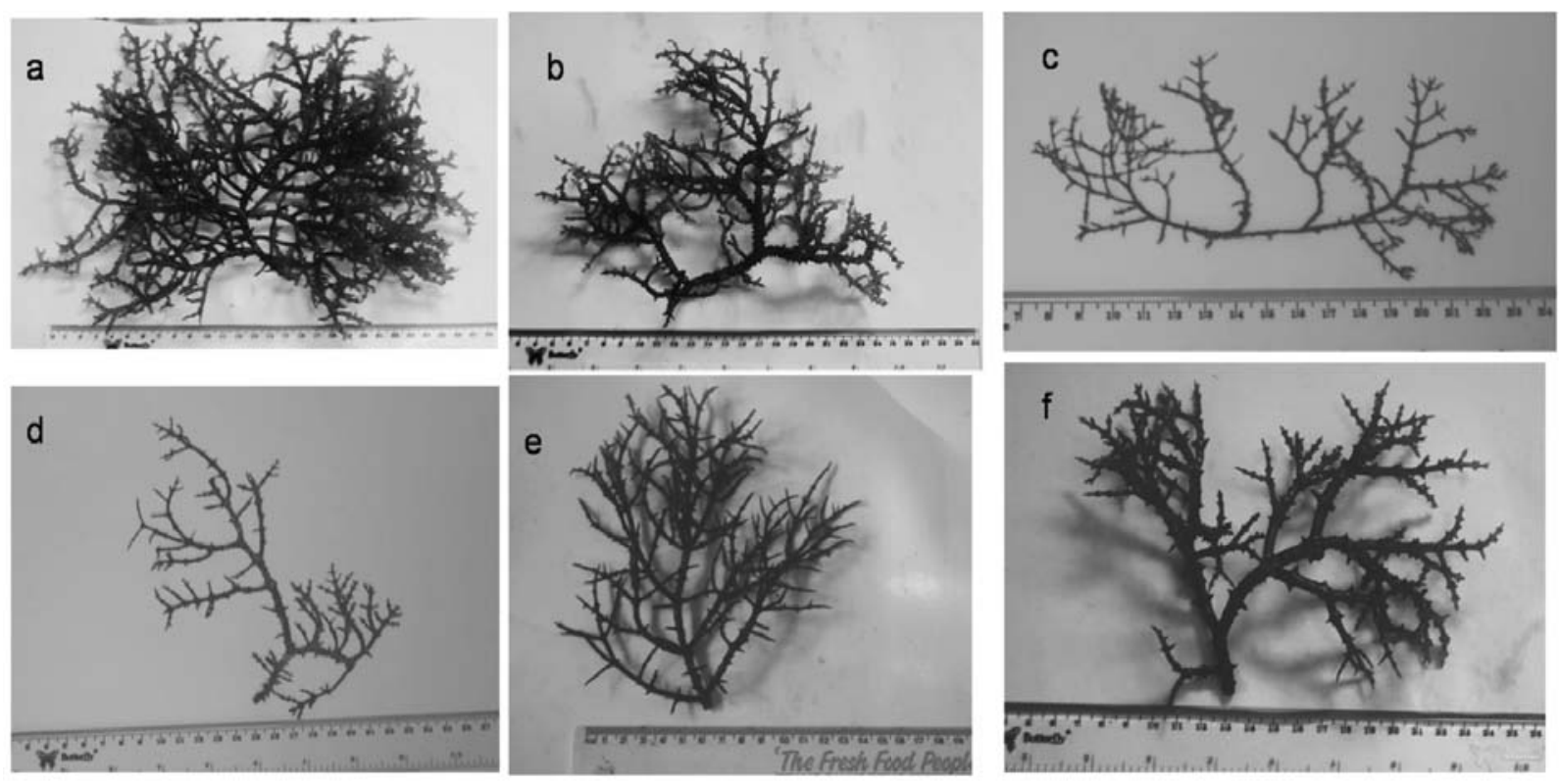

Figure 6. Six ecotypes of E. spinosum collected from Nusa Tenggara Barat, at Gili Indah, North Lombok (a), Pengantap,West Lombok (b), Bangko-Bangko, West Lombok (c), Gili Genting, West Lombok (d), Tanjung Ann, Central Lombok (e) and Teluk Ekas, Est Lombok (f)
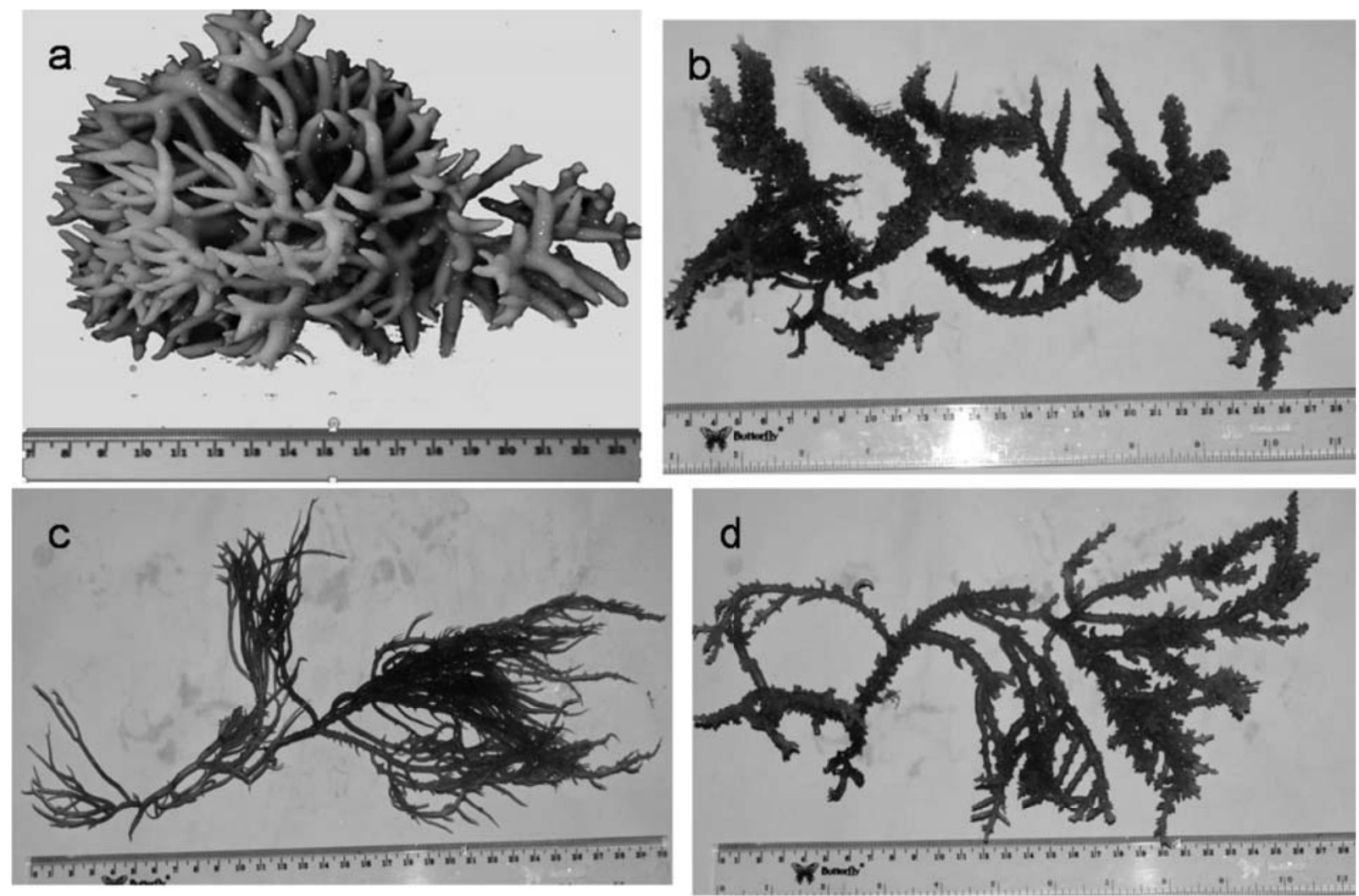

Figure 7. Four ecotypes of uncharacterized Eucheuma/Kappaphycus from Nusa Tenggara Barat are Eucheuma/Kappaphycus sp. 1 (a; Pulur, East Lombok), Eucheuma/Kappaphycus sp. 2 (b; Jelenge, West Sumbawa), Eucheuma/Kappaphycus sp. 3 (c; Jelenge, West Sumbawa), Eucheuma/Kappaphycus sp. 4 (d; Kaung, West Sumbawa). 
Table 2. Ecotypes of Kappaphycus and Eucheuma varieties obtained in Nusa Tenggara Barat

\begin{tabular}{|l|l|l|}
\hline No & Location & Species \\
\hline 1 & Gili Indah (Gili Genting, Gili Meno and Gili Terawangan; West Lombok & E. spinosum \\
\hline 2 & Gili Genting & E. spinosum \\
\hline 3 & Bangko-bangko & E. spinosum \\
\hline 4 & Tanjung Ann (Central Lombok) & E. spinosum \\
\hline 5 & Teluk Ekas (East Lombok) & E. spinosum \\
\hline 6 & Pulur (East Lombok) & Eucheuma/Kappaphycus sp.1 \\
\hline 7 & Jelenge (Sumbawa) & Eucheuma/Kappaphycus sp.2 \\
\hline & & Eucheuma/Kappaphycus sp.3 \\
\hline 8 & Teluk Kaung (Sumbawa & Eucheuma/Kappaphycus sp.4 \\
\hline
\end{tabular}

Table 3. Characteristics of ecotypes of Kappaphycus and Eucheuma varieties obtained in Nusa Tenggara Barat

\begin{tabular}{|c|c|c|c|}
\hline No & Sample & Varian & Thallus morphology \\
\hline \multirow[t]{3}{*}{1} & E. spinosum & Spinosum (Gili Indah) & $\begin{array}{l}\text { Thallus color is brown. It has robust, hard and } \\
\text { cartilaginous thalli with pointed end. The thallus is } \\
\text { cylindrical with irregular-type branches, has no nodule } \\
\text { and pointed spines which later develop into branches. } \\
\text { The diameter of primary and secondary thalli is less than } \\
0.3 \mathrm{~cm} \text {. The height of primary thalli is less than } 10 \mathrm{~cm} \text {. } \\
\text { There are more than } 15 \text { and } 25 \text { spines in primary and } \\
\text { secondary thalli respectively. The height of branches } \\
\text { is less than } 10 \mathrm{~cm} \text { while the height of spine is between } \\
0.4-0.5 \mathrm{~cm} \text { and distance between each spine is more than } \\
0.05 \mathrm{~cm} \text {. Holdfast is present. }\end{array}$ \\
\hline & & Spinosum (Gili Genting) & $\begin{array}{l}\text { Thallus color is brown. It has robust, hard and } \\
\text { cartilaginous thallus with pointed end. The thallus is } \\
\text { cylindrical with irregular-type branches, has rough } \\
\text { surface, has pointed spine which later develop into } \\
\text { branches. The diameter of primary and secondary thalli } \\
\text { is less than } 0.3 \mathrm{~cm} \text {. The height of primary thalli is less } \\
\text { than } 10 \mathrm{~cm} . . \text { There are more than } 15 \text { and } 25 \text { spine in } \\
\text { primary and secondary thalli respectively. The height of } \\
\text { branches is more than } 10 \mathrm{~cm} \text { while the height of spine } \\
\text { is between } 0.3-0.5 \mathrm{~cm} \text { and distance between each spine } \\
\text { is less than } 0.05 \mathrm{~cm} \text {. Holdfast is present. }\end{array}$ \\
\hline & & Spinosum (Bangko-Bangko) & $\begin{array}{l}\text { Thallus color is light brown. It has robust, hard and } \\
\text { cartilaginous thallus with pointed end. The thallus is } \\
\text { cylindrical with verticillate branches, smooth surface, } \\
\text { has pointed spines which later develop into branches. } \\
\text { The diameter of primary and secondary thalli is less } \\
\text { than } 0.3 \mathrm{~cm} \text {. The height of primary thalli is less than } \\
10 \mathrm{~cm} \text {.. There are less than } 10 \text { spines in primary thallus } \\
\text { and more than } 15 \text { spines in the branch. The height of } \\
\text { branches is more than } 10 \mathrm{~cm} \text { while the height of spine } \\
\text { is between } 0.3-0.5 \mathrm{~cm} \text {, distance between each spine is } \\
\text { less than } 0.05 \mathrm{~cm} \text {. Holdfast is present. }\end{array}$ \\
\hline
\end{tabular}




\begin{tabular}{|c|c|c|c|}
\hline & & Spinosum (Tanjung Ann) & $\begin{array}{l}\text { Thallus color is light brawn with some dots, hard and } \\
\text { cartilaginous thallus with pointed end. The thallus is } \\
\text { cylindrical with verticillate branches, smooth surface, } \\
\text { has pointed spines which later develop into branches. } \\
\text { The diameter of primary and secondary thallus is less } \\
\text { than } 0.3 \mathrm{~cm} \text {. The height of primary thalli is less than } \\
10 \mathrm{~cm} \text {.. There are less than } 10 \text { spines in primary thalli } \\
\text { and more than } 15 \text { spines in the branch. The height of } \\
\text { branches is more than } 10 \mathrm{~cm} \text { while the height of spines } \\
\text { is between } 0.3-0.5 \mathrm{~cm} \text {, distance between each spine is } \\
\text { less than } 0.05 \mathrm{~cm} \text {. Holdfast is present. }\end{array}$ \\
\hline & & Spinosum (Teluk Ekas) & $\begin{array}{l}\text { Thallus color is greenish brown, hard and cartilaginous } \\
\text { thallus with pointed end. The thallus is cylindrical with } \\
\text { verticillate branches, smooth surface, has pointed spines } \\
\text { which later develop onto branches. The diameter of } \\
\text { primary and secondary thalli is less than } 0.3 \mathrm{~cm} \text {. The } \\
\text { height of primary thalli is less than } 10 \mathrm{~cm} \text {. There are } \\
\text { less than } 10 \text { spines in primary thalli and more than } 15 \\
\text { spines in the branch. The height of branches is more } \\
\text { than } 10 \mathrm{~cm} \text { while the height of spine is between } 0.3-0.5 \\
\mathrm{~cm} \text {, distance between each spine is less than } 0.05 \mathrm{~cm} \text {. } \\
\text { Holdfast is present. }\end{array}$ \\
\hline 2 & $\begin{array}{l}\text { Eucheuma/ } \\
\text { Kappaphycus sp-1 }\end{array}$ & Pulur (East Lombok) & $\begin{array}{l}\text { Thallus color whitish brawn, hard and thallus with } \\
\text { pointed end. The thallus is cylindrical with irregular-type } \\
\text { branches appearing in the main thallus, rough surface and } \\
\text { has no spines and sub-branches. The diameter of primary } \\
\text { and secondary thalli is more than } 0.5 \mathrm{~cm} \text {. The height } \\
\text { of primary thalli is less than } 10 \mathrm{~cm} \text { and secondary thalli } \\
\text { is less than } 5 \mathrm{~cm} \text {. Holdfast is present. }\end{array}$ \\
\hline \multirow[t]{3}{*}{3} & $\begin{array}{l}\text { Eucheuma/ } \\
\text { Kappaphycus sp-2 }\end{array}$ & Jelenge (West Sumbawa) & $\begin{array}{l}\text { Cystocarpic, thallus color brawn, hard and cartilaginous } \\
\text { thallus with blunt end. The thallus is cylindrical with } \\
\text { irregular branching, few branches, rough surface and } \\
\text { has blunt and dense spines. The diameter of primary and } \\
\text { secondary thallus is more than } 0.5 \mathrm{~cm} \text {. The height of } \\
\text { primary thallus is about } 10 \mathrm{~cm} \text { and secondary thallus is } \\
\text { less than } 7 \mathrm{~cm} \text {. Holdfast is present. }\end{array}$ \\
\hline & $\begin{array}{l}\text { Eucheuma/ } \\
\text { Kappaphycus sp-3 }\end{array}$ & Jelenge (West Sumbawa) & $\begin{array}{l}\text { Thallus color brown, hard and cartilaginous thallus } \\
\text { with blunt or pointed end. The thallus is cylindrical } \\
\text { with verticillate branches, smooth surface, has irregular } \\
\text { spines and sub-branches. The diameter of primary } \\
\text { and secondary thallus is less than } 0.5 \mathrm{~cm} \text {. The height } \\
\text { of primary and secondary thalli is more than } 10 \mathrm{~cm} \text {. } \\
\text { Holdfast is present. }\end{array}$ \\
\hline & $\begin{array}{l}\text { Eucheuma/ } \\
\text { Kappaphycus sp-4 }\end{array}$ & Teluk Kaung (Sumbawa) & $\begin{array}{l}\text { Cystocarpic, thallus color brown, hard and cartilaginous } \\
\text { thallus with blunt end. The thallus is cylindrical with } \\
\text { irregular branching, rough surface, and has blunt spines, } \\
\text { dense spines and sub-branches. The diameter of primary } \\
\text { and secondary thallus is more than } 0.5 \mathrm{~cm} \text {. The height } \\
\text { of primary and secondary thalli is about } 10 \mathrm{~cm} \text {. Holdfast } \\
\text { is present. }\end{array}$ \\
\hline
\end{tabular}



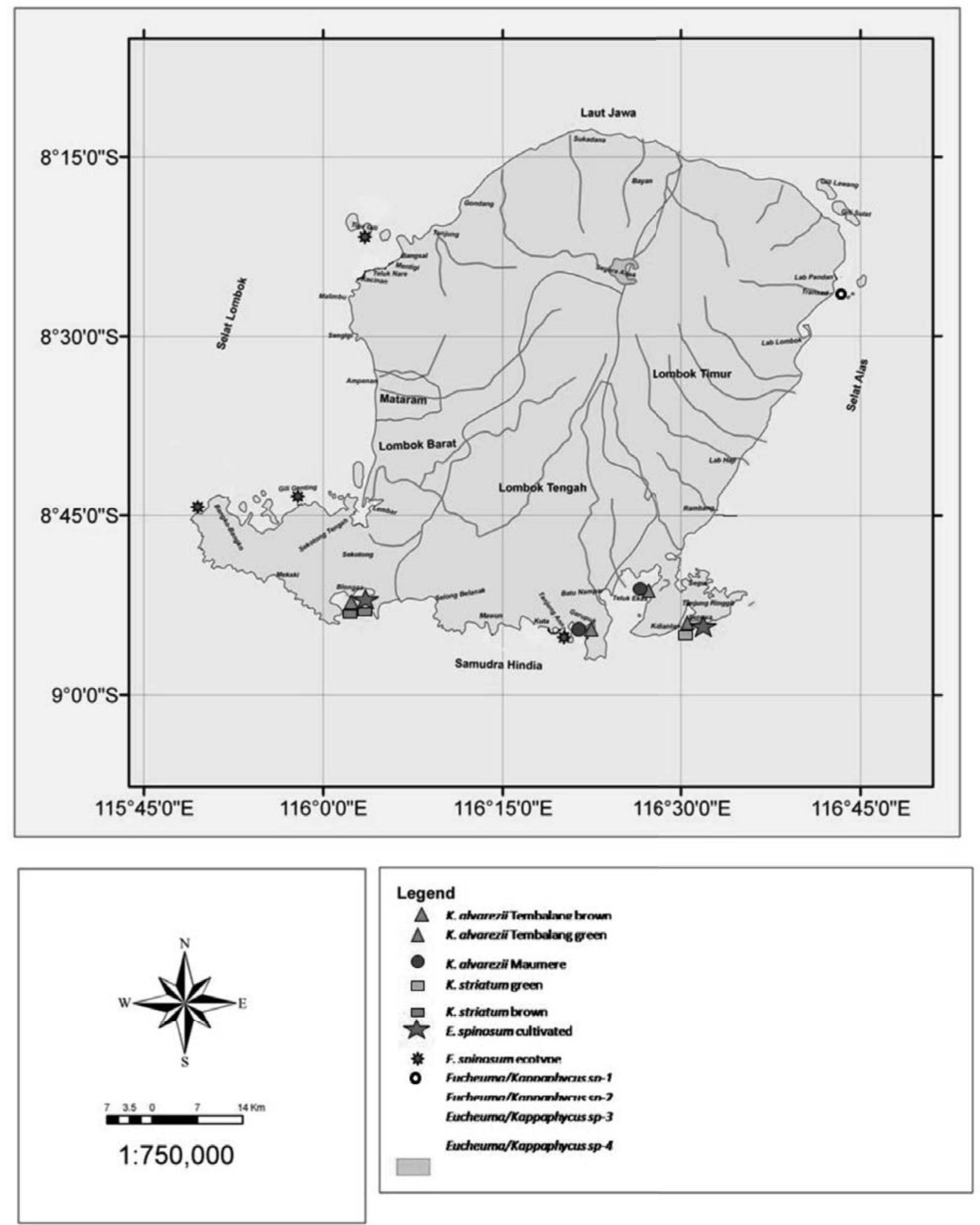

Figure 8. Distribution of of Kappaphycus and Eucheuma varieties in Nusa Tenggara Barat 
Lombok Island is more variable than that in Sumbawa Island. The seaweeds farmed in Lombok Island comprise of K. alvarezii (Tambalang brown and green as well as well as Moumere), E. stiatum (green and brown), and E. spinosum. In Sumbawa Island, there is no $E$. spinosum cultivation. The morphology of cultivated Kappaphycus alvarezii strains are somewhat similar, with some variation in color, shape and size of thallus and clumps. The phenotypic plasticity of seaweed as a response to environment, including Kappaphycus and Eucheuma, have been well documented [6] [7]. However within the cultivated species, the Kappaphycus strain in Nusa Tenggara Barat can be easily identified as there are few morphological variations; this is probably due to quite similar environmental conditions in the cultivation areas. This is also reflected in the similar quantities of carrageenan produced by the species at different locations in Nusa Tenggara Barat. In addition, cultivated Kappaphycus can be separated from the $K$. striatum and E. spinosum due to distinct morphological

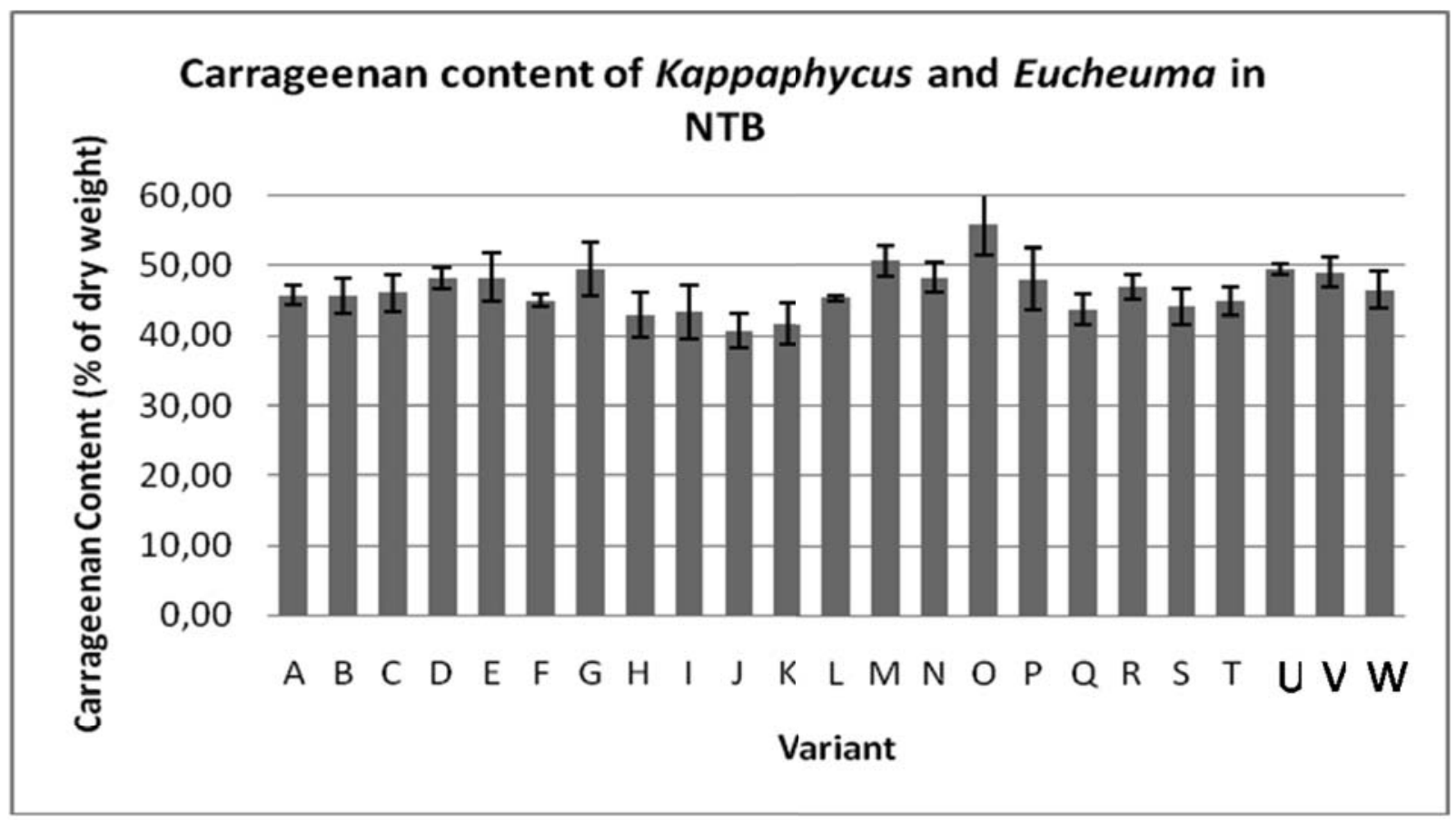

Figure 9. Amplified cox2-3 spacer from cultivated/wild specimens of Kappaphycus/Eucheuma from NTB. Line 1: 1KB plus DNA ladder, line 2 to 9 E. spinosum and K. striatum samples from NTB.

differences between the three varieties. Difficulties in identification were experienced with the ecotypes (wild specimens). It was initially suggested that there are more than one species of Eucheuma/Kappaphycus obtained in Lombok Island, and the Lombok ecotype may differ from the Sumbawa ecotype as there is much variation in the morphology (Figure 8). However, molecular analysis of mitochondrial cox 2-3 spacer reveals that the ecotype obtained in Lombok and Sumbawa Islands are essentially the same species of Eucheuma denticulatum. Interestingly, the ecotype and the cultivated strain (as cultivated in Serewe Bay and called "spinosum" by the locals) are essentially Eucheuma denticulatum. The presence of cultivated Eucheuma denticulatum in Lombok Island (in Ekas Bay and Serewe bay) has been reported previously [5], [8], [9], [10] and the sequence of $E$. denticulatum as reported in this paper is very similar to those previously reported by [5],[8],[9], [10]. However, to the best of our knowledge, the presence of the same species in Sumbawa Island has not been reported previously. Further study is now underway to assess the genetic diversity of other wild species of Eucheuma and Kappaphycus in Nusa Tenggara Barat. 


\section{ACKNOWLEDGEMENT}

We sincerely thank the Indonesian Ministry of Higher Education (Dikti) for the International Collaboration Research Grant allowing this research to be undertaken.

\section{REFERENCES}

1. De Ruiter GA, Rudolph B (1997). Carrageenan Biotechnology. Trends in Food Science and Technology 8 (12): 389-395

2. Mabeau S, Fleurence J (1993). Seaweed in food products: Biochemical and nutritional aspects.

3 Ask E, Batibasaga A, Zertuche-González JA, de San Ask M (2003). Three decades of Kappaphycus alvarezii (Rhodophyta) introduction to nonendemic locations. Proceedings of International Seaweed Symposium 17: 49-58.

4. Nurhayati (2009). Rising Sea Temperature, Bad News for Seaweed Farmers. The Jakarta Wed, October 282009

5. Tan Ji, Phaik-Eem Lim \& Siew-Moi Phang (2013). Phylogenetic relationship of Kappaphycus Doty and Eucheuma J. Agardh (Solieriaceae, Rhodophyta) in Malaysia. J. Applied Phycol. 25: 13-29. DOI: $10.1007 / \mathrm{s} 10811-012-9833-1$

6. Mathieson AC, Norton TA, Neushul (1981). The taxonomic implication of genetic and environmentally induced variations in seaweed morphology, The Botanical Review 43 (3): 313347).

7. Kimberly YC, Kurihara A, Sherwood AR (2009). A molecular method for identification of the morphologically plastic invasive algal genera Eucheuma and Kappaphycus (Rhodophyta, Gigartinales) in Hawaii. Journal of Applied Phycology, 21 (6): 691-699.

8. Jie T, Lim PE, Phang SM, Hong DD, Sunarpi H, Hutado AQ (2012). Assessment of Four Molecular Markers as Potential DNA Barcodes for Red Algae Kappaphycus Doty and Eucheuma J. Agardh (Solieriaceae, Rhodophyta). PloS One 7 (12): e52905

9. Zuccarello GC, Critchley AT, Smith J, Sieber V, Lhonneur GB, West JA ( 2006). Ssytematics and genetic variation in commercial Kappaphycus and Eucheuma (Solieriaceae, Rhodophyta). Journal of Applied Phycology 18: 643-651. DOI: 10.1007/ s10811-006-9066-2

10. Zuccarello GC, West JA (2004). Molecular phylogeny of the subfamily Bostrychioideae
(Ceramiales, Rhodophyta): subsuming Stictosiphonia and highlighting polyphyly in species of Bostrychia. Phycologia 45: 24-36.

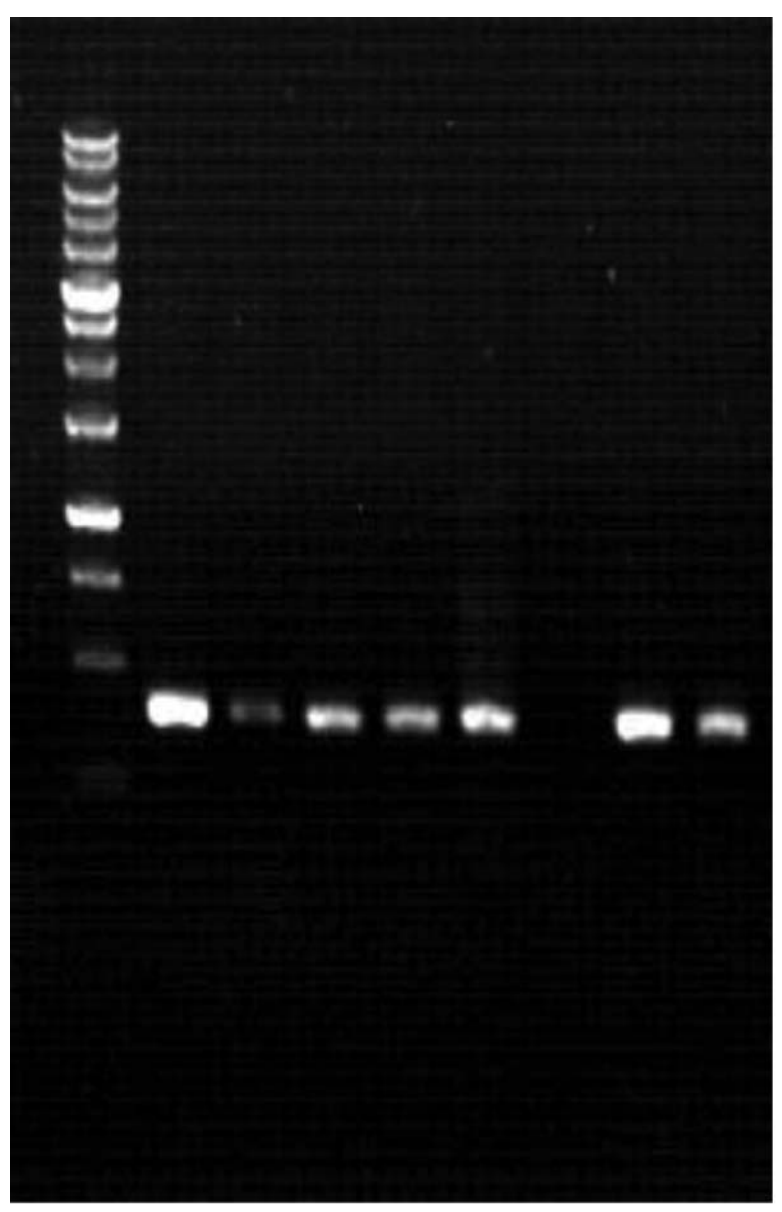

Figure 10. Amplified cox2-3 spacer from cultivated/wild specimens of Kappaphycus/Eucheuma from NTB. Line 1: 1KB plus DNA ladder, line 2 to $9 \mathrm{E}$. spinosum and $K$. striatum samples from NTB 
Table 4. Characteristics of cultivated Kappaphycus and Eucheuma varieties obtained in Nusa Tenggara Barat

\begin{tabular}{|c|c|c|c|}
\hline No & Sample & Varian & Thallus morphology \\
\hline \multirow[t]{2}{*}{1} & \multirow[t]{2}{*}{ E. spinosum } & Spinosum (Pengantap) & $\begin{array}{l}\text { Thallus color is light brown. It has robust, hard and } \\
\text { cartilaginous thallus with pointed end. The diameter } \\
\text { of primary and secondary thallus is less than } 0.5 \mathrm{~cm} \text {. } \\
\text { There are more than } 10 \text { branches in primary thallus and } \\
\text { primary thallus height is less than } 10 \mathrm{~cm} \text {. The thallus } \\
\text { is cylindrical with fverticillate branches, has no nodule } \\
\text { and blunt spines which later develop into branches. The } \\
\text { height of branches is less than } 10 \mathrm{~cm} \text { while the height of } \\
\text { spine is between } 0,4-0,5 \mathrm{~cm} \text { and distance between each } \\
\text { spine is more than } 0.05 \mathrm{~cm} \text {. Holdfast is present. }\end{array}$ \\
\hline & & Spinosum (Serewe) & $\begin{array}{l}\text { It has a dark brown, cartilaginous, cylindrical, robust and } \\
\text { hard thallus with pointed-end. The thallus is cylindrical } \\
\text { with rough spinal surface, verticillate branches, has } \\
\text { no nodule and blunt spines which later develop into } \\
\text { branches. The diameter of primary and secondary thallus } \\
\text { is less than } 0.5 \text { and } 0.2 \mathrm{~cm} \text { respectively. Each bunch is } \\
21-25 \mathrm{~cm} \text { wide and } 16-20 \mathrm{~cm} \text { in height. There are about } \\
11 \text { to } 15 \text { spines in primary thallus and primary thallus } \\
\text { height is between } 11 \text { to } 20 \mathrm{~cm} \text {. The height of branches is } \\
\text { less than } 11-20 \mathrm{~cm} \text { while the height of spine is between } \\
0.2-0.3 \mathrm{~cm} \text { and distance between each spine is between } \\
0.05 \text { to } 0.3 \mathrm{~cm} \text {. Holdfast is absent. }\end{array}$ \\
\hline \multirow[t]{3}{*}{2.} & \multirow[t]{3}{*}{ K. alvarezii } & Tambalang green (Pengantap) & $\begin{array}{l}\text { It has a dark green, cartilaginous, cylindrical, robust } \\
\text { and smooth thallus with pointed-end. The thallus is } \\
\text { cylindrical with irregular-type of branching, has no spine } \\
\text { but has nodule and holdfast. The diameter of primary } \\
\text { and secondary thallus is more than } 1 \mathrm{~cm} \text {. Each bunch is } \\
16-20 \mathrm{~cm} \text { in wide and } 16-20 \mathrm{~cm} \text { in height. The height } \\
\text { of primary thallus is between } 16 \text { and } 20 \mathrm{~cm} \text {. The height } \\
\text { of branches is between } 11-20 \mathrm{~cm} \text {. }\end{array}$ \\
\hline & & Tambalang green (Gerupuk) & $\begin{array}{l}\text { The thallus is light green, cartilaginous, cylindrical, } \\
\text { robust and smooth thallus with pointed-end. The thallus } \\
\text { is cylindrical with irregular-type of branches, has no } \\
\text { spine but has nodule and holdfast. The diameter of } \\
\text { primary and secondary thallus is more than } 1 \mathrm{~cm} \text {. Each } \\
\text { bunch is } 16-20 \mathrm{~cm} \text { wide and } 16-20 \mathrm{~cm} \text { in height. The } \\
\text { height of primary thallus is between } 20 \text { and } 30 \mathrm{~cm} \text {. The } \\
\text { height of branches is between } 11 \text { and } 25 \mathrm{~cm} \text {. }\end{array}$ \\
\hline & & Tambalang brown (Gerupuk) & $\begin{array}{l}\text { It has light brown, cartilaginous, cylindrical, robust } \\
\text { and smooth thallus with pointed-end. The thallus is } \\
\text { cylindrical with irregular-type of branches, has no spine } \\
\text { but has nodule and holdfast. The diameter of primary } \\
\text { and secondary thallus is more than } 1 \mathrm{~cm} \text {. Each bunch is } \\
11 \text { - } 15 \mathrm{~cm} \text { wide and } 16-20 \mathrm{~cm} \text { in height. The height of } \\
\text { primary thallus is less than } 20 \mathrm{~cm} \text {. The height of branches } \\
\text { is between } 11 \text { and } 25 \mathrm{~cm} \text {. }\end{array}$ \\
\hline
\end{tabular}


Malaysian Journal of Science 32 (SCS Sp Issue) : 127-140 (2013) 